DOI: 10.1515/auseb-2017-0004

\title{
Analysis of Local Economic Development Capacity in Hungarian Rural Settlements
}

\author{
Krisztián RITTER, ${ }^{1}$ Henrietta NAGY ${ }^{2}$
}

\author{
${ }^{1}$ Associate professor, Deputy Director - Institute for Regional Economics and Rural \\ Development, Faculty for Economic and Social Sciences, Szent István University \\ Gödöllő, ritter.krisztian@gtk.szie.hu \\ ${ }^{2}$ Associate professor, Vice-Dean - Institute for Regional Economics and Rural \\ Development, Faculty for Economic and Social Sciences, Szent István University \\ Gödöllő, nagy.henrietta@gtk.szie.hu
}

\begin{abstract}
Besides local economic development (LED) theories, especially LED practices have a growing importance nowadays. By a primary research involving more than 400 actors (local governments, local entrepreneurs, local agencies), the necessary competencies, practical experiences, and the field of further skills and extension concerning cooperation in economic development of localities were analysed. Summing up the research results, both local governments and local entrepreneurs have certain lack of competence that has to be improved, while the need of this exercise (and LED as a whole) for an appropriate financial background and a national strategy/policy is wellemphasized by the answers of the actors.
\end{abstract}

Keywords: innovation, local economic development, rural areas, rural economy

JEL: O18, P25, R00

\section{Introduction}

Localization is one of the most important forces forming the economic space, while local places connect to the global economy in several ways. The role of the local level is emphasized by the two main principles of the EU's territorial policy: subsidiarity and decentralization. Based on these principles, the decisions and actions have to be done on that level which has the optimal overview and competency for that. The literature of LED does not have a commonly agreed term for “local” (see e.g. Dicken, 2003; Lengyel, 2003; Nemes-Nagy, 1998, Swinburn 
et al., 2004; Temple, 1994). As a specific approach in this paper, local is defined on the settlement (local government) level.

The role of the local governments in local economic development planning is underlined even in the Hungarian and international literature (e.g. Douglas, 2005; Martin, 2001; Ritter, 2000; Swinburn et al., 2004.) Meanwhile, based on the declining local possibilities, the economic analysis of the small rural settlements, and concerning the findings of national and international researches aiming at settlement and territorial development (e.g. Byrden \& Hart, 2004; G. Fekete, 2005; Káposzta, 2014; Picchy, 1994; Ritter, 2014), our hypothesis was that smaller settlements have only partial competencies for LED.

Based on subsidiarity and decentralization, decisions and execution should be delegated to the level where the highest competency is available to carry out the tasks. Due to such principles, the responsibility of the local level increases, while more and more local demands, ideas, and resources are activated. Strengthening local competence is important in moderating the national level to be able to cross the national borders (Rechnitzer \& Smahó, 2006).

"Locality" is also important because local associations may balance the impacts of globalization, while its various impacts on everyday life are perceived by mass population rather in their local/regional appearance (Agg \& Nemes Nagy, 2002). The importance of the regional and local units has already been emphasized in the National Spatial Development Concept (Országos Területfejlesztési Koncepció-OTK, 2005) as well, declaring that the basic aim is to enable the regions and cities of Hungary to become more competitive, thus contributing to the economic and social catch-up of the country to the European Union average. Regional competitiveness focuses on the ability of regions to attract and keep external resources as well as to improve the competitiveness of the regional players while building up an efficient regional structure. In order to improve the competitiveness of enterprises, a harmonized regional development is needed (e.g. location, informatics, accessibility, finances, consultancy, qualified human resource, public administration, etc.). To attract and keep the qualified population in the region, viable environment, positive regional image, high-quality services, adequate cultural and retail supply are necessary in addition to the proper jobs. To use development funds locally, an active, flexible, and efficient management is needed which is able to generate, realize competitive projects and represent its interests in the partnership-based development policy. The key to competitiveness is the cooperative ability of the region's actors. Therefore, encouraging regional economic cooperation (e.g. research institutes, multinational companies, cooperation of SMEs and consultancy firms) is of high importance (OTK, 2005).

Today's economic spatial structure is shaped by both globalization and localization. Basically, the importance of the national level has relatively 
decreased, and regions and local actors often enter the global economy directly (without the intermediary role of the national level). Based on the operation of the companies, it can be stated that local level plays an important role not only in the case of local businesses and SMEs (offering most of the local jobs) but also in the case of transnational companies. From a company success point of view, local approach is really important since real interference into the economic processes can be realized at the local level (Bajmóczy, 2011). This brings the need for local development strategies to the frontline that is based on endogenous resources, encourages the cooperation of local actors, and is built in a bottomup manner (Káposzta, 2014; Nagyné, 2007) as the typical philosophy of EU’s LEADER program (see Kassai \& Farkas, 2007).

Local economy comprises harmonized and conscious actions, activities, people, institutions, resources, and procedures based on and motivated by local conditions. Its development is a planned interference into the economic processes to achieve sustainable local development. It aims at creating a sustainable local economy, a well-operating internal market for local businesses, and at providing an adequate standard of living and jobs for the local population (Mezei, 2006a; Swinburn et al., 2004).

In this paper, against the usually general approach of regional economy, the settlement level is considered to be "local". Under the present economic, social, and environmental conditions, the key to success for any settlement is whether it is able to adapt to the ever-changing local, national, and international market economy. Local Economic Development is applied where strengthening of the local economic capacities, improvement of the businesses' competitiveness and productivity are in the focus. The key factor is the involvement of local actors who participate either as initiators or formulators and supporters of external development ideas, and that depends highly on the social capital (see e.g. Kassai, 2014; Molnár, 2013; Tóth \& Jóna, 2012). Interfering into the market processes can be carried out only based on community approval; thus, local municipalities cannot be left out from the local economic developments. However, to achieve success, additional contributors are also needed since it should be based on the cooperation of the business sphere, the community, and the local government.

Cooperation has an important role in LED. One of its important features is that local actors (economy and society) cooperate to encourage local economic activities, do actions which fit the local conditions, based on local resources so that they could meet present and new demands as well. The common thinking of the business sphere, the local government, and the local population and their common actions can help the local community to maintain the local values and use the opportunities while adapting to the changing local and external conditions, improving adaptability. Local actors do not reject the cooperation with the surrounding environment; 
moreover, they strive to achieve "symbiosis" by sharing work and functions with the external economy. Therefore, local economy is somehow "introvertal" since it aims at meeting the local demand by local businesses, but, of course, it is embedded into a broader economic environment.

One important factor of adapting to globalization is how strong the link is between the local organizations and institutions, while the local development success also depends on the strong coalition and institutional cooperation of local players (Horváth, 2000). It requires organized cooperation. Experiences (e.g. Bogárdi \& Molnár, 2014; Mezei, 2006b; Némediné \& Neszmélyi, 2015; Swinburn et al., 2004) prove that local governments have significant coordination, mediation, and initiative role due to the low level of organization in the case of other actors (civil and business sphere). International experience clearly emphasizes the role of local governments in relation with the development of rural areas as well (e.g. Douglas, 2005; Martin, 2001).

Local economy can be developed by human, financial, or infrastructural instruments - the most efficient method is if several instruments and methods are combined without priorities and compile a conscious program built on each other. Among the instruments, professional literature names community development, production and sale of local products, development of local businesses, financing local economy, encouraging local collaborations and local economic activities of municipalities, social economy, vocational training based on local needs and interest as well as shaping the approach of population and entrepreneurs. Like other spatial development activities, planning is a key priority in local economic development. The result of planning is the elaboration of a strategy. Therefore, it is extremely important for a settlement to have such a strategy since efficient developments can only be realized along well-planned strategies. However, based on national and international research results (e.g. Lengyel, 2003; Ritter, 2014), we should state that due to the lasting impacts of the economic crisis and the limited local resources, small settlements usually do not have enough competencies to fulfil such tasks.

This is the reason why this paper concentrates on settlement level as "local" and tries to investigate the necessary competencies, practical experiences, and the field of further skills and extension concerning the cooperation in economic development.

The "Material and Methods" section introduces the main aims, the conditions, and circumstances of the research with detailed methodology. The "Results and Discussions" section focuses on the most relevant and important results of the primary research, while in "Conclusions" the paper tries to sum up useful statements and suggestions based on the results and experiences. 


\section{Material and Methods}

This research provided help to project ED_13-1-2013-0020 („Képzési rendszer megvalósítása az önkormányzatok gazdaságfejlesztési feladatainak támogatására” - Creating an educational system helping the economic development activities of local governments), which defines a training serving the joint preparation of local governments, entrepreneurs, and civil organizations, with special focus on economic and entrepreneurship studies as well as management and organizational competencies supporting the cooperation of the participants. First, the conditions, competencies as well as the roles of the participants had to be surveyed. Accordingly, the survey had the following aims:

- To examine how well the participants are prepared and what practical experience they have in economic development;

- To see how the players evaluate each other;

- To see in what economic sectors they have good or bad experience and which best practices they consider useful;

- To see what practice they have in cooperation and with what results.

This research concentrated on two groups, namely the local governments and the local businesses/entrepreneurs (as well as the associations representing their interest). The role of local governments is unquestionable in the local economic development, while businesses have two roles: on the one hand, they actively take part in it; on the other hand, they are its target group as well. It is necessary to achieve common thinking and to enable the actors to learn about each other's situation and intentions before they start working together. Therefore, it is inevitable for the employees of local governments to learn entrepreneurship and business to enable them to cooperate. In addition, it is necessary for the businessmen to change their attitudes and to develop their competencies about settlement operation, legislation as well as settlement/ regional development. Based on the abovementioned, our aim was to find out the preparedness and practical experience of players in economic development tasks, how they evaluate each other, and what the necessary competencies are to achieve success.

Peripheral rural areas with a low number of population are characterized by facing problems in local economic development (see e.g. Káposzta et al., 2010; Mezei, 2006b). In accordance with it, we intended to examine settlements with population under 3,000. We defined the sample in the counties by the number of settlements under 3,000 (compared to the number of settlements in each county), the number of people living in such settlements compared to the total population. In order to achieve national representability in the survey, settlements and businesses had been selected randomly. The local business associations in the selected area were targeted directly. During the survey, we intended to question 
the government officers and the businessmen from the same settlements so that we can compare their responses and find out the cooperation between them. During the primary research, we used questionnaires and in-depth interviews as well. The research was carried out by the colleagues and students of the Szent István University in October and November 2015.

\section{Results and Discussions}

This paper focuses on the major results of the research. 210 local governments, 210 local businesses, and 57 regional affiliations/representatives of three organizations (Entrepreneur-Development Foundations, Chamber of Commerce and Industry, Chamber of Agriculture) were questioned. All the settlements have population under $3,000.80 \%$ of the settlements are with population under $2,000.40 \%$ of the local governments had fewer than 5 full-time employees, $29 \%$ had 6-10 employees, while $87 \%$ of the governments did not employ anybody/did not have any departments that were expert in economic development. $65 \%$ of the entrepreneurs employed 5 or fewer people, $16 \%$ employed 6-15 people, $7 \%$ employed 16-45 people, and only $2 \%$ had over 45 employees.

Thus, it can be stated that most of the respondents were from the SME sector. We examined whether despite the availability of experts local governments had local economic development strategies ${ }^{1}$ (Figure 1).

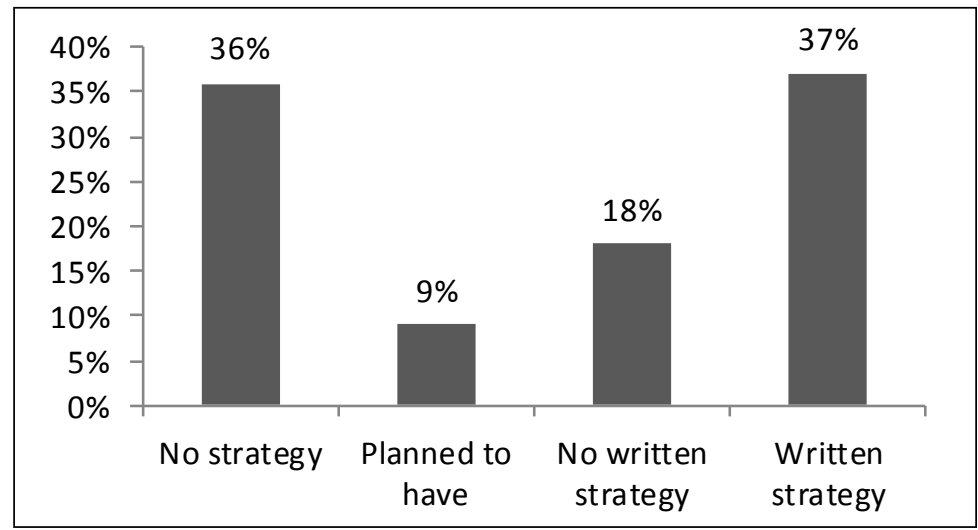

Source: own research and calculation, 2015

Figure 1. The share of local governments having economic development strategy (\%)

1 The elaboration of strategy might not have direct relationship with the fact if there are experts available or not since strategies might be elaborations by external consultants as well. 
$37 \%$ of the local governments reported that they had written economic development strategy, ${ }^{2}$ while $36 \%$ did not have such at all. $9 \%$ was planning to prepare the strategy in written form or electronically. $18 \%$ were operated by some strategy which was not in writing.

Overall, it can be stated that only two-fifths of the settlements had their economic development strategy documented. We intended to compare the existence of strategy with the opinion of local businesses (Figure 2).

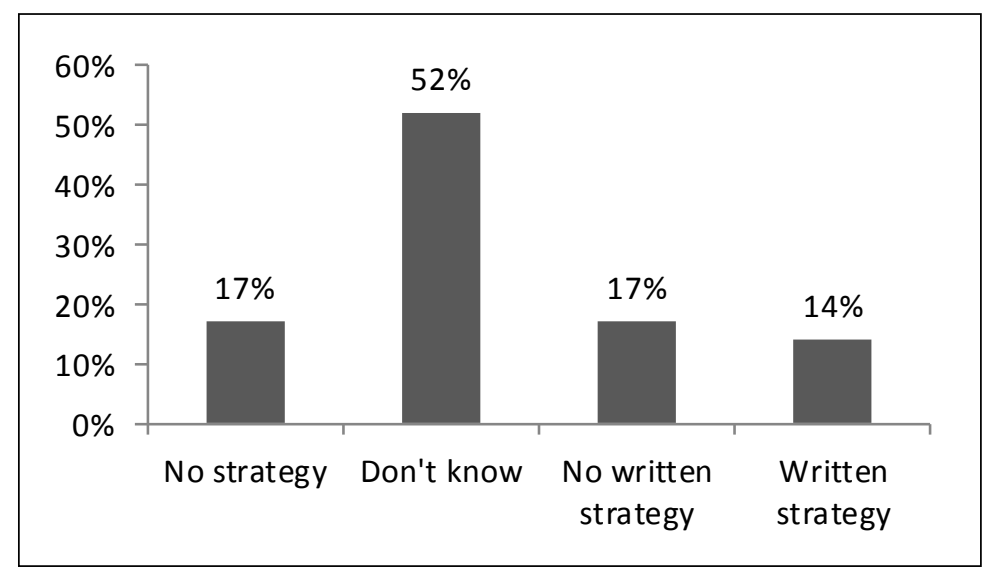

Source: own research and calculation, 2015

Figure 2. Responses of entrepreneurs

about the economic development strategies of the local governments (\%)

$14 \%$ of entrepreneurs thought that the settlement had economic development strategy in written form, while $17 \%$ said there was no existing strategy. $52 \%$ did not know about strategy or did not have information about the development strategy. $17 \%$ thought that there was a strategy, but it was not in writing.

We also asked the local governments (having no written form) about the lack of strategy, and $34 \%$ defined the lack of funds or human resource, while $19 \%$ mentioned the low number of employees as the reason. Other reasons were e.g. the lack of need for the strategy or that the conditions and endowments of the settlement are not proper for such strategies or just it is not required by the law.

It was also important to see what opinion the two spheres have about their relationship and about the harmony between their plans. According to $50 \%$ of the local governments (Figure 3 ) and $35 \%$ of businesses (Figure 4), the harmony is quite moderate. $22 \%$ of the businesses said that the plans of the local government

$252 \%$ of those with a strategy had it prepared in 2015 . In 2014 , less than $40 \%$ had strategy. Just 8\% prepared it in 2013 or even earlier. 
and the businesses were not in line, while $11 \%$ of the local governments had the same opinion.

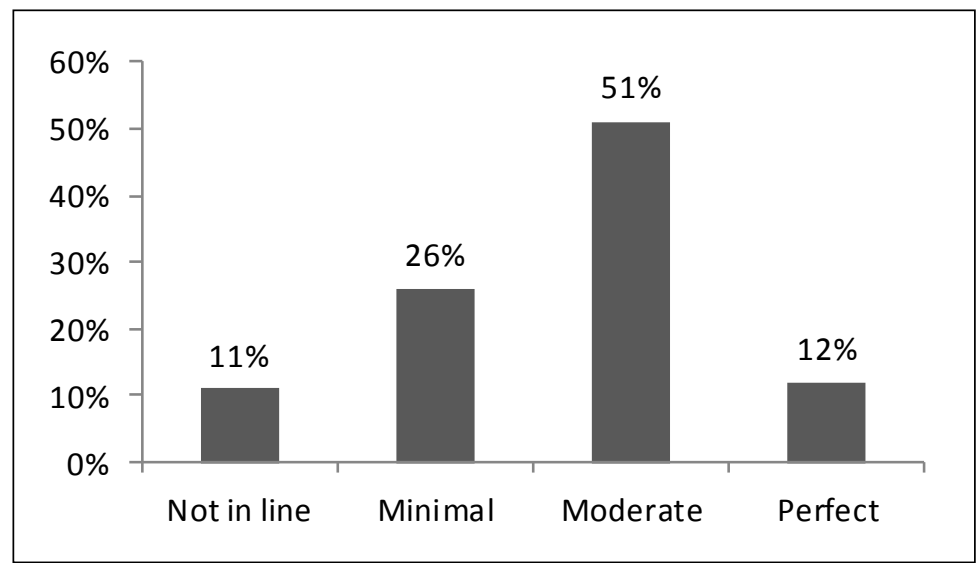

Source: own research and calculation, 2015

Figure 3. Responses of the local governments about the harmony between the activities of the government and the local businesses (\%)

However, it should be emphasized that $12 \%$ of the local governments, while only $8 \%$ of the businesses thought that there was total harmony between the plans and actions of the two spheres.

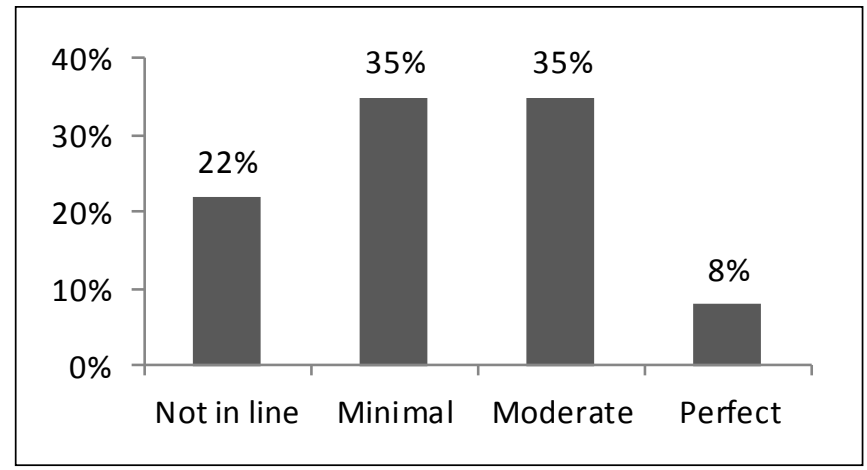

Source: own research and calculation, 2015

Figure 4. Responses of the local businesses about the harmony between the activities of the government and the local businesses (\%) 
Local governments mentioned as reasons for poor collaboration e.g. the lack or low number of businesses, the small size of businesses, the economic power of businesses, or the fact that the profiles of the businesses did not justify the cooperation. The different interests, the lack of communication due to the unconcern of the other party were also mentioned. According to the businessmen, the local governments do not have any idea how to manage a settlement economically. Many respondents said that there was a lack of experts, proper attitude, qualification, and coherence.

That is why it is important to see how the players consider (from 1 to 4 ) the competencies and knowledge of the other actors in relation with economic development (Table 1).

Table 1. The evaluation of knowledge necessary for economic development by actors

\begin{tabular}{lcccc}
\hline \multirow{2}{*}{ Actors of economic development } & \multicolumn{2}{c}{$\begin{array}{c}\text { Responses } \\
\text { by local governments }\end{array}$} & \multicolumn{2}{c}{$\begin{array}{c}\text { Responses } \\
\text { by businesses }\end{array}$} \\
\cline { 2 - 5 } & Mean & Deviation & Mean & Deviation \\
\hline Local government & 2.64 & 0.84 & 2.29 & 0.87 \\
\hline Local businesses & 2.57 & 0.78 & 2.59 & 0.77 \\
\hline Other regional businesses & 2.71 & 0.78 & 2.61 & 0.79 \\
\hline Professional associations & 2.62 & 0.82 & 2.58 & 0.96 \\
\hline Civil organizations & 1.95 & 0.78 & 1.99 & 0.79 \\
\hline Central government & $\mathbf{3 . 3 1}$ & 0.75 & $\mathbf{2 . 7 5}$ & 0.94 \\
\hline Local population & 1.79 & 0.72 & 1.61 & 0.75 \\
\hline External experts, consultants & $\mathbf{3 . 1 4}$ & 0.80 & $\mathbf{2 . 9 4}$ & 0.91 \\
\hline $\begin{array}{l}\text { Higher educational institutions, } \\
\text { research centres in the region }\end{array}$ & $\mathbf{3 . 0 9}$ & 0.85 & $\mathbf{2 . 7 7}$ & 0.98 \\
\hline
\end{tabular}

Note: rank 1-4 (1: to a small extent, 4: to a large extent)

Source: own research and calculation, 2015

According to the opinion of the local governments, the central government has the most proper knowledge (3.31) necessary for economic development. The knowledge of external experts, consultants (3.14) as well as of the higher educational institutions and research centres (3.09) is adequate, which could be a good basis for defining the economic development priorities. Other businesses in the regions (2.71), local governments (2.64), professional organizations (2.62), and the local business sphere (2.57) received only satisfactory evaluation from the local governments for their knowledge. Based on the responses, civil organizations and the local population had 
the least knowledge; however, in our opinion - regarding the embeddedness of local developments -, their importance in elaborating strategies cannot be questioned.

Businessmen said that external experts and consultants had the most necessary competencies. They are followed by the higher educational institutions and research centres in the region (2.77), the government (2.75), other businesses in the region (2.61), the local business sphere (2.59) as well as the associations representing interests (2.58). Local governments had only average knowledge, while civil organizations and local population had the least knowledge. In the questionnaire, we intended to find out what actors the respondents had had cooperated with during local development projects (Table 2).

Table 2. Share of collaborators and the most active collaborators among the respondents (\%)

\begin{tabular}{|c|c|c|c|}
\hline Collaboration with: & & Local gov. & Businesses \\
\hline \multirow{2}{*}{$\begin{array}{l}\text { Local government/local } \\
\text { government of other settlements }\end{array}$} & Collaborated & 27 & 39 \\
\hline & Most active & 12 & 18 \\
\hline \multirow[t]{2}{*}{ Local businesses } & Collaborated & 21 & 38 \\
\hline & Most active & 14 & 11 \\
\hline \multirow[t]{2}{*}{ Other businesses in the region } & Collaborated & 23 & 24 \\
\hline & Most active & 3 & 4 \\
\hline \multirow[t]{2}{*}{ Professional organizations } & Collaborated & 12 & 23 \\
\hline & Most active & 5 & 2 \\
\hline \multirow[t]{2}{*}{ Civil organizations } & Collaborated & 13 & 36 \\
\hline & Most active & 4 & 10 \\
\hline \multirow[t]{2}{*}{ County-level government } & Collaborated & 8 & 32 \\
\hline & Most active & 3 & 7 \\
\hline \multirow[t]{2}{*}{ Local action group (leader) } & Collaborated & 14 & 28 \\
\hline & Most active & 3 & 9 \\
\hline \multirow[t]{2}{*}{ Touristic organizations } & Collaborated & 12 & 24 \\
\hline & Most active & 4 & 3 \\
\hline \multirow[t]{2}{*}{ Clusters } & Collaborated & 7 & 10 \\
\hline & Most active & 2 & 2 \\
\hline \multirow{2}{*}{$\begin{array}{l}\text { Higher educational institutions, } \\
\text { research centres }\end{array}$} & Collaborated & 8 & 16 \\
\hline & Most active & 1 & 3 \\
\hline
\end{tabular}

Note: more than one answer could be marked as a collaborator, while only one could be indicated as the most active collaborator. 
The respondents could mark more than one answer, but the most active cooperating partner had to be indicated. As for the local governments, they had the most common collaboration with other local governments, local and regional businesses, while the rarest collaboration was with clusters or higher educational institutions. As for the local businesses, they cooperated the most with the local government, other local businesses and civil organizations, while the rarest collaboration was with clusters.

We considered it inevitable to see what actions and measures would serve the strengthening of the collaboration between the local governments and the local business actors. Respondents had to mark the three most important instruments (Table 3).

Table 3. Distribution of proposed actions to improve cooperation (\%)

\begin{tabular}{|c|c|c|}
\hline \multirow[t]{2}{*}{ Instruments to develop cooperation } & By local government & By businesses \\
\hline & \multicolumn{2}{|c|}{$(\%)$} \\
\hline Development of communication channels & 55 & 59 \\
\hline Regular meetings & 30 & 25 \\
\hline Informal share of information & 32 & 39 \\
\hline Administrative assistance & 17 & 31 \\
\hline Organizing joint courses & 23 & 22 \\
\hline $\begin{array}{l}\text { Organizing common free-time/cultural } \\
\text { programs }\end{array}$ & 36 & 22 \\
\hline $\begin{array}{l}\text { Strengthening the involvement of } \\
\text { businesses in local decision-making }\end{array}$ & 36 & 62 \\
\hline $\begin{array}{l}\text { Common idea-generating activities (e.g. } \\
\text { idea box, brainstorming) }\end{array}$ & 51 & 37 \\
\hline
\end{tabular}

Note: more than one answer (max. 3) could be marked

Source: own research and calculation, 2015

Local governments emphasized the development of communication channels (regular information, meetings, e-mails $-55 \%$ ), common brainstorming (51\%), while $62 \%$ of entrepreneurs saw the key to cooperation in strengthening the local businesses and $59 \%$ would have welcomed the development of communication channels.

\section{Conclusions}

The most important conclusion that can be drawn from our research is that in small (and mainly rural) settlements there is a lack of capacity and expertise 
which would be necessary to carry out local developments. In addition, local businessmen do not have the necessary knowledge to understand the settlement development issues, which are much broader than the company's ones. Overall, there is a lack of ability that would bring about economic development based on local cooperation. In order to create cooperation - which is regularly emphasized in theories -, both players should learn each other's competencies and activities to be able to take part in the complex actions of local economic development.

All in all, for two-thirds of the entrepreneurs, the settlements where they are located do not provide a local economic frame/strategy for their activities. Regarding planning the future, more attention should be paid to the communication between the local governments and the businesses since if businesses do not know whether the settlement has a strategy or not, it is like if there were not any at all.

Both local governments and businesses were questioned about how important they considered innovations and learning new skills/competences in their own field. $94 \%$ of the local governments and $90 \%$ of the businesses thought that innovation and improving competences were important. It were the only issue in which they agreed nearly $100 \%$.

Collaboration can be observed between the two parties; however, not in a structured and organized form and not in economic development. They usually cooperate ad-hoc. The players responded that there was a moderate harmony between their activities. They considered a key task to create and emphasize mutual interest.

Those who are the most involved and interested in local (!) economic development believed that external players, the government, external experts, or the higher educational institutions were the key to success. On the one hand, this highlights that small settlements could not adopt the endogenous local development approach yet, while, on the other hand, it calls the attention to the potential role of universities in initiation - especially in improving competencies.

As a conclusion, the most important problems that should be addressed are the development of communication channels, the strengthening of the local businesses, and brainstorming. None of the parties considered important organizing joint courses. However, we highly encourage such initiatives - especially based on the former research findings.

Based on our research, we suggest the development of cooperation between the two parties, the improvement of competencies/skills as well as the elaboration of the necessary strategy and raising the necessary funds. 


\section{References}

Agg, Z.; Nemes Nagy, J. (2002). A politika térségi és helyi szintjei [The regional and local levels of politics]. In: Bernek Á. (ed.), A globális világ politikai földrajza [Political geography of the global world]. Budapest: Nemzeti Tankönyvkiadó, 385-430.

Bajmóczy, Z. (2011). Bevezetés a helyi gazdaságfejlesztésbe [Introduction to local economic development]. Szeged: JATEPress.

Bogárdi, T.; Molnár, M. (2014). The barriers to economic development through the example of a Hungarian internal periphery. Vestnik Apk Stavropolya/ Agricultural Bulletin of Stavropol Region 1(1): 52-55.

Bryden, J.; Hart, K. (eds.) (2004). Why local economies differ: the dynamics of rural areas in Europe. New York: Edwin-Mellen Press.

Dicken, P. (2003). Global shift. Reshaping the global economic map in the $21^{\text {st }}$ century. London: SAGE.

Douglas, D. (2005). The restructuring of local government in rural regions: a rural development perspective. Journal of Rural Studies (21): 231-246.

G., Fekete É. (2005). Új esély a perifériának? [New chance for the peripheries?] Falu-Város-Régió 1-2: 44-46.

Horváth, Gy. (2000). Partnerség az Európai Unió regionális politikájában [Partnership in the EU's regional policy]. Tér és Társadalom (1): 11-26.

Kassai, Zs. (2014). Measuring social capital in rural development partnerships. In: Neszmélyi, Gy. I. (ed.), Socio-economic and regional processes in the developing countries. Gödöllő: SZIE Publishing, 167-175.

Kassai, Zs.; Farkas, T. (2007). A LEADER+ program alulnézetből [The LEADER+ program from a bottom view]. Comitatus 17(5): 71-79.

Káposzta, J. (2014). Területi különbségek kialakulásának főbb összefüggései [The main contexts of emerging territorial differencies]. Gazdálkodás 58(5): 399412.

Káposzta, J.; Nagy, H.; Kollár, K. (2010). Borsod-Abaúj-Zemplén és Szabolcs-SzatmárBereg megye leghátrányosabb helyzetú kistérségeinek települési szerkezeti, foglalkoztatási jellemzői az EU csatlakozás óta eltelt időszakban [The settlement and employment characteristics of the most disadvantaged micro-regions in Borsod-Abaúj-Zemplén and Szabolcs-Szatmár-Bereg counties since the EU accession]. Területi Statisztika 50(6): 641-658.

Lengyel, I. (2003). Verseny és területi fejlődés: térségek versenyképessége Magyarországon. [Competition and territorial development: competitiveness of regions in Hungary]. Szeged: JATEPress.

Martin, J. (2001). Economic and community development through innovative local government. Sustaining Regions 1(1): 5-12. 
Mezei, C. (2006a). A helyi gazdaságfejlesztés fogalmi meghatározása [Definition of local economic development]. Tér és Társadalom (4): 85-96.

(2006b): A települések versenyképességét befolyásoló helyi gazdaságfejlesztési gyakorlat Magyarországon [Practice of local economic development influencing settlement competitiveness in Hungary]. In: Horváth, Gy. (ed.), Régiók és települések versenyképessége [Competitiveness of regions and settlements]. Pécs: MTA RKK, 413-442.

Molnár, M. (2013). Factors of success in case of local society. Deturope: Central European Journal of Tourism and Regional Development 5(3): 63-70.

Nagyné, M. M. (2007). A területi egyenlőtlenségek főbb összefüggései [The main correlations of territorial inequalities]. In: Káposzta, J. (ed.), Regionális gazdaságtan [Regional economy]. Debrecen: DE AMTC AVK, 166-205.

Nemes Nagy, J. (1998). A tér a társadalomkutatásban [Space in social research]. Budapest: Hilscher Rezső Szociálpolitikai Egyesület.

Némediné, K. K.; Neszmélyi, Gy. (2015). Aspects of spatial economic processes of disadvantaged areas in Hungarian and international perspective. Romanian Review of Regional Studies: Journal of the Centre for Regional Geography 11(2): 67-83.

OTK (2005). Országos Területfejlesztési Koncepció [National Spatial Development Concept]. Budapest: Országos Területfejlesztési Hivatal.

Picchy, A. (1994). The relations between central and local powers as context for endogenous development. In: Ploeg, J. D.; Long, A. (eds), Born from within. Practice and perspectives of endogenous rural development. Assen: Van Gorcum, 195-203.

Rechnitzer, J.; Smahó, M. (2006). Regionális politika [Regional policy]. Győr: Széchenyi István University.

Ritter, K. (2000). Az önkormányzati társulások, a településközi együttmúködés jelentősége a terület- és vidékfejlesztésben [Importance of local governmental cooperations in territorial and rural development]. Területi Statisztika (1): 17-29.

Ritter, K. (2014). Possibilities of local economic development (LED) in lagging rural areas. Acta Carolus Robertus 4(1): 101-108.

Swinburn, G.; Goga, S.; Murphy, F. (2004). A helyi gazdaságfejlesztés kézikönyve [Handbook of local economic development]. Gütersloh: Bertelsmann Stiftung; London: UK DFID; Washington D. C.: The World Bank.

Temple, M. (1994). Regional Economics. Basingstone: Palgrave Macmillan.

Tóth, T.; Jóna, Gy. (2012). Concepts of the Territorial Capital. Selye E-Studies (3): $1-15$. 